\title{
The Kaliningrad Region's Industry, Problems and Prospects of Development and Restructuring in the Context of a Special Economic Zone (SEZ)
}

\author{
Yury M. Zverev \\ Immanuel Kant Baltic Federal University, Russian Federation \\ Corresponding Email: YZverev@kantiana.ru
}

Doi:10.5901/mjss.2015.v6n6s7p321

\begin{abstract}
The article is devoted to changes in the Russian Kaliningrad region's industry since the early 2000s' under the influence of the Special Economic Zone (SEZ). The main outcome of the changes was the restructuring of the regional industry, in which new import-substituting manufacturers operating in the national market began to play the key role. End of the SEZ customs privileges on 1 April 2016 (while preserving tax concessions by 2031) as well as Russia's accession to the WTO make the further development of the SEZ in the context of import substitution extremely difficult. In this regard, the paper discusses the prospects for further development of the Kaliningrad region's industry in the changed and changing conditions.
\end{abstract}

Keywords: Russia, Kaliningrad region, industry, manufacturing, restructuring, free/special economic zone (SEZ)

\section{Introduction}

At the end of the 1980's the industry played an important role in the economy of the Kaliningrad region. Three sectors played the key role in the sector structure, i.e. mechanical engineering, fishing and the pulp-and-paper industry. In the future, two interrelated circumstances had a major impact on the development of Kaliningrad's industry apart from those common to Russia's transition in general. The transformation of the region into an exclave separated from Russia by foreign states and the creation in 1991 of a free economic zone (SEZ), and in 1996 a special economic zone (SEZ). These factors led to a deeper recession in the Kaliningrad industry than in Russia as a whole. In 1998, the industrial production in the region decreased by six times compared to 1990. In fact, that was deindustrialisation of the region. The processes occurring in the period were described by Fedorov and Zverev $(1995,2002)$, Gareev et al. (2005), Khlopetsky and Fedorov (2000), Klemeshev et al. (2002), Zverev (2006), Fedorov (2011) to name just a few.

Since 1999-2000, the economy of the Kaliningrad region and Russia as a whole began to recover slowly from the recession. The production growth was particularly strong in industry with the industrial growth to a great extent being supported by the SEZ regime established by the federal law in 1996 and modified by the new law of 2006. In this article we analyse how the SEZ regime influenced the structure and dynamics of the Kaliningrad industry (primarily the manufacturing sector), what prospects it opened and problems posed, what possible growth areas of the exclave region's industry might be considered taking into account all that.

\section{Recovery of the Industrial Growth in the Kaliningrad Region and the Major Growth Factors}

In 2000, the industrial production growth, which interrupted the decline of the transition period in 1992-1999, resumed in the Kaliningrad region. In 2000-2014, the annual industrial production index in the Kaliningrad Region was almost always higher than nationwide (Fig. 1, Table 1). 


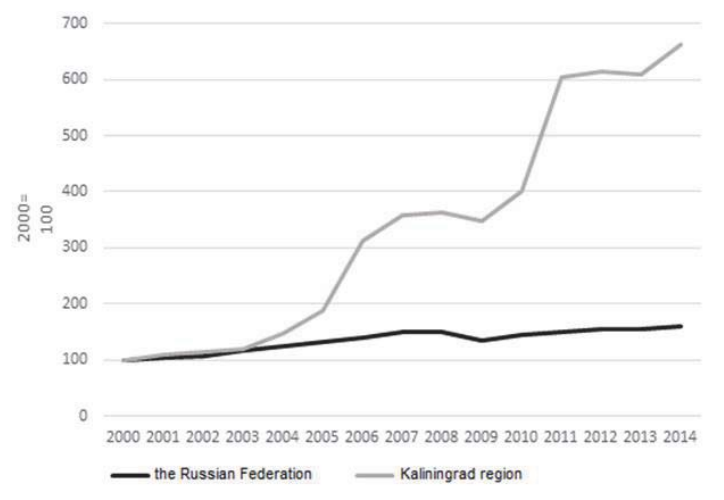

Figure 1. Industrial production growth, as a percentage of 2000

Source: compiled by the author based on Regions of Russia (2002, 396); The Industrial Production Index by the Constituent Territories of the Russian Federation (2015).

Table 1. The industrial production index in Russia and the Kaliningrad region (in \% to the previous year) in the 2000-2014

\begin{tabular}{|c|c|c|c|c|c|c|}
\hline & 2000 & 2001 & 2002 & 2003 & 2004 & 2005 \\
\hline Russia & 108.7 & 102.9 & 103.1 & 108.9 & 108,0 & 105,1 \\
\hline \multirow[t]{2}{*}{ Kaliningrad region } & 117.0 & 110.1 & 104.2 & 104.7 & 122,5 & 127,4 \\
\hline & 2006 & 2007 & 2008 & 2009 & 2010 & 2011 \\
\hline Russia & 106.3 & 106.8 & 100.6 & 89.3 & 107,3 & 105,0 \\
\hline \multirow[t]{2}{*}{ Kaliningrad region } & 166.6 & 114.4 & 101.8 & 95.3 & 116,0 & 150,1 \\
\hline & 2012 & 2013 & 2014 & & & \\
\hline Russia & 103.4 & 100.4 & 101.7 & & & \\
\hline Kaliningrad region & 101.9 & 99.1 & 108.7 & & & \\
\hline
\end{tabular}

Source: compiled by the author based on the Industrial Production Index by the Constituent Territories of the Russian Federation (2015).

The key factors contributed to the rapid industrial growth as follows:

- Development through the free customs zone of the SEZ in 1996 extended to 2016, and the tax benefits of the SEZ in 2006 associated with the import-substituting industries focusing on the Russian national market;

- Increased demand in the Russian domestic market due to the growth of incomes of the companies and citizens;

- Increased attention to the region from the federal authorities, one of the most important factors in attracting investment to the region from other parts of Russia (mainly Moscow and St. Petersburg);

- Proximity to foreign sources of raw materials, components and semi-finished products.

The SEZ regime, as mentioned above, contributed to the emergence of new production with major emphasis on the Russian national market. There entire new industries, which had not previously existed (e.g. automotive, production of TV sets and other consumer electronics etc.), emerged. Some industries, which had been previously presented quite vaguely (furniture and meat-packing industry), grew significantly. For a number of new for her industrial products The Kaliningrad region started to take up noticeable or even leading positions in the Russian Federation. For example, before the crisis in 2009 , the Kaliningrad region was producing about $75 \%$ of all the Russian TV sets and about $84 \%$ of vacuum cleaners, UAB Avtotor, a closed joint-stock company was the largest producer of foreign cars in Russia (Denisenkov, 2009), (Report on the Performances of the Special Economic Zone ... , 2007), Avtotor will increase the production of cars by 2.3 times (2010). At the same time, it also continued to figure prominently in the production of some of the traditional industrial products (food fish products (including canned fish), fish and seafood, pulp and paper, vodka, liqueurs, spirits etc.).

However, the import-substituting production facilities operating on imported raw materials and components are highly dependent on the stability of supply of raw materials, semi-finished products and components from abroad as well 
as the demand in the Russian national market on which their products are focused.

In this context, it should be borne in mind that the Kaliningrad region's industrial growth was of a recovery nature to an even greater extent than the whole country because of the greater depth of recession. In 2000, the volume of industrial production in the Kaliningrad region accounted for only 19\% of the 1990 level (52\% the whole of Russia) (Fig. 2).

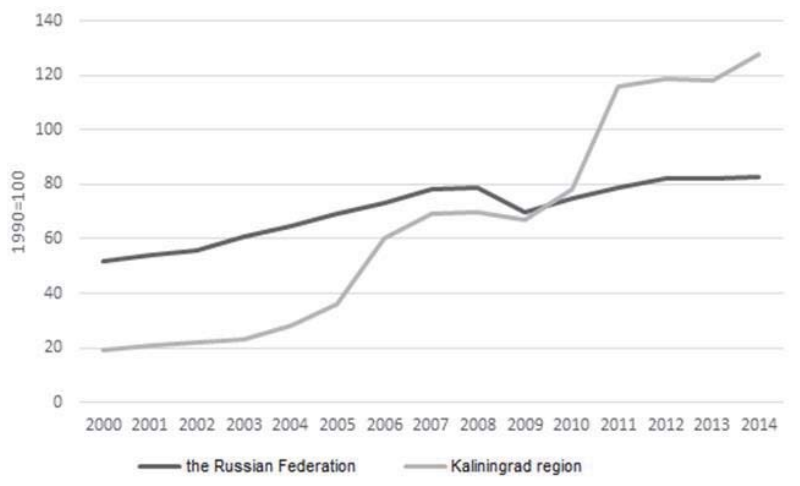

Figure 2. Industrial production growth as a percentage of 1990

Source: compiled by the author based on the Regions of Russia $(2002,396)$; The Industrial Production Index by the Constituent Territories of the Russian Federation (2015).

\section{Manufacturing Activities of the Kaliningrad Region, Structural Changes}

Manufacturing forms the core of the Kaliningrad region's industries, the share of which in 2014 accounted for $22.9 \%$ of the added gross value generated by all types of economic activities, and $11.5 \%$ of the value of fixed assets. In the same year, the manufacturing sector employed 55,000 people. (17\% of all those employed in the Kaliningrad region's economy) (Kaliningrad Region in 2015 Figures (2015).

According to the territorial body of the Federal State Statistics Service in the Kaliningrad region, the majority of the industrial enterprises are quite small. Only UAB Avtotor and JSC Baltic Shipyard Yantar have more than 3,000 employees, Viciunai-Rus Ltd, JSC Moloko, JSC Kaliningrad Packaging Mill and Produkty Pitaniya Ltd from 1,000 to 1,500 .

The data on changes in the structure of the manufacturing sector for 2004-2014 are shown in Table 2. Unfortunately, due to the introduction in 2003 of a new Russian Classification of Economic Activities (OKVED) is not possible to perform a comparison with 2000.

Table 2. Structure of the shipped goods of own production, works and services by own resources in the Kaliningrad region's manufacturing industry in 2004, 2010 and 2014 (in \%)

\begin{tabular}{lccc}
\hline & $\mathbf{2 0 0 4}$ & $\mathbf{2 0 1 0}$ & $\mathbf{2 0 1 4}$ \\
\hline Manufacturing - total & 100 & 100 & 100 \\
of which: manufacture of food products, beverages and tobacco & 35.7 & 27.4 & 28.9 \\
textile and clothing manufacture & 2.7 & 1.5 & 0.6 \\
production of leather, leather products and footwear & 0.0 & 0.0 & 0.0 \\
wood working and production of wood products & 0.7 & 0.5 & 0.4 \\
pulp-and-paper industry; publishing and printing & 6.1 & 1.7 & 1.2 \\
chemical production & 1.4 & 0.8 & 1.3 \\
manufacture of rubber and plastic products & 0.8 & 0.9 & 0.8 \\
manufacture of other non-metallic mineral products & 3.5 & 1.3 & 1.3 \\
metallurgical production and production of finished metal products & 3.8 & 2.2 & 1.9 \\
manufacture of machinery and equipment & 5.7 & 2.5 & 1.7 \\
manufacture of electrical equipment, electronic equipment and optical equipment & 29.4 & 16.2 & 8.7 \\
manufacture of transport vehicles and equipment & 6.3 & 42.4 & 51.7
\end{tabular}




\begin{tabular}{lccc}
\hline & $\mathbf{2 0 0 4}$ & $\mathbf{2 0 1 0}$ & $\mathbf{2 0 1 4}$ \\
\hline other production & 2.4 & 2.6 & 1.5 \\
\hline
\end{tabular}

Source: compiled by the author based on the Kaliningrad Region in Figures 2009 (2009, 78), Kaliningrad Region in Figures $2015(2015,91)$.

It should be noted that among the most significant structural changes in the manufacturing sector of the Kaliningrad region for 2004-2014, first of all, it is a more than three-fold drop in the share of the production of electrical and optical devices and an increase in the share of the production of transport vehicles and equipment by more than eight times. In addition, the proportion of pulp-and-paper production decreased by more than five times.

The regional cluster for the production of consumer electronics (mainly TV sets) has sharply declined since 2009 due to the following factors:

- The global economic crisis in 2008-2009 under which major manufacturers loaded their production to the maximum extent possible taking orders from the licensed ones (in 2009, such A-brands as Sony and Panasonic left the Kaliningrad region. Currently, there are almost no A-brand productions left in the region's television cluster area, and the Kaliningrad manufacturers are working mainly with the B-brands);

- Decline in the domestic demand in the down economy;

- Abolishment in accordance with the government resolution dated 11 September 2008 N 659 (in force until December 2010) of the customs duties on the import into Russia of plasma modules (screens) and liquid crystal displays thus depriving the Kaliningrad assemblers of the SEZ benefits;

- Establishment by major brands of production facilities in other regions of Russia;

- Customs problems on the border with the Republic of Belarus associated with the supply of products to the main part of the Russian Federation;

- The fall in the rouble exchange rate in 2014 and the consequent rise in the prices of components (Yu.M. Zverev describes in more detail about the impact of the crisis in 2008-2009 on the Kaliningrad region's industry, 2010).

The growing share of the production of transport vehicles and related equipment is primarily due to the expansion of car production by UAB Avtotor (16,500 cars produced in 2005, 265,000in 2012 and 186,000 in 2014) (Afanasyev, 2006), in 2014 Avtotor will reduce the production of cars (2013), Avtotor resumed the production of cars in Kaliningrad after a break (2015) and the revival of naval shipbuilding in the Baltic Shipyard Yantar.

The pulp-and-paper industry, which was once one of the Kaliningrad region's specialised areas, has shrunk dramatically in size. The related enterprises ceased production in the pulp-and-paper industry in Kaliningrad, Znamensk and Sovetsk. Paper is now produced only in Neman (of the imported pulp).

Thus, the structure of the manufacturing sector is now dominated by food production (mainly fish processing, meat and milk) and the production of transport vehicles and equipment. In 2013 they accounted for more than 3/4 of the shipped goods of own production, works and services by own forces in the manufacturing industry, $57.5 \%$ of the value of fixed assets of large and medium-sized enterprises and organisations in the manufacturing sector and more than $45 \%$ of the average number of employees hired by enterprises and organisations in the manufacturing sector (Table. 3 ).

Table 3. Sectoral structure of the Kaliningrad region's manufacturing sector in $2013, \%$ of total

\begin{tabular}{lccc}
\hline & $\begin{array}{c}\text { Volume of the shipped goods } \\
\text { of own production, works and } \\
\text { services by own efforts }\end{array}$ & $\begin{array}{c}\text { Fixed assets of large and medium- } \\
\text { sized enterprises and organisations }\end{array}$ & $\begin{array}{c}\text { Average number } \\
\text { of employees }\end{array}$ \\
\hline Manufacturing - total & 100 & 100 & 100 \\
of which: manufacture of food products, beverages and & 22.3 & 46.8 & 33.5 \\
tobacco & 0.9 & 0.4 & 5.3 \\
textile and clothing manufacture & 0.0 & $\ldots$ & 0.3 \\
production of leather, leather products and footwear & 0.3 & 2.6 & 2.0 \\
wood working and production of wood products & 1.7 & 4.0 & 4.9 \\
pulp-and-paper industry; publishing and printing & 2.7 & 10.7 & 1.1 \\
chemical production & 0.7 & 9.2 & 3.2 \\
manufacture of rubber and plastic products & 1.5 & 3.5 & 3.5 \\
manufacture of other non-metallic mineral products & 1.5 & 4.6 & 3.6
\end{tabular}


manufacture of electrical equipment, electronic equipment and optical equipment

10.9

manufacture of transport vehicles and equipment

other production
54.4

1.7
5.4

10.7

0.4
7.6

12.1

21.0

Source: compiled by the author based on the Kaliningrad Region's Industry (2013).

\section{Problems and Prospects of the Kaliningrad Region's Industry}

The Kaliningrad region's industry remains to be mainly import-substitutive and based on the use of the SEZ (especially customs) benefits and focusing on the Russian national market. The majority of import-substituting industries can be characterised by a very low share of value added (on average it is only $18 \%$ for manufacturing) (Gimbitsky et al., 2014).

The focus on innovation by import-substituting companies and the Kaliningrad economy as a whole is low. In 2013, the proportion of organisations implementing technological innovations in the Kaliningrad region's total number of organisations amounted to just 3.8\%, which is by almost 2.5 times lower than even the extremely low Russian national average (8.9\%) (the proportion of the organisations engaged in technological innovations, 2013).

Most of the Kaliningrad region's industrial enterprises are insufficiently connected or not connected with each other in the production and processing chain.

A characteristic feature of the import-substituting industry set up under the SEZ is its 'fragility', dependence on the world market and the state of the Russian national market. In addition, the enclave economy is more than other Russian regions' economies dependent on the relations between Russia and the EU as proved by the situation with sanctions and countersanctions in connection with the events in Ukraine. The medium- and long-term prospects of most types of the production and economic activities in the WTO context and termination of the transitional regime in the SEZ in 2016 are considered to be negative (with the exception of mining, production, transmission and distribution of electricity, gas and water) (Zhdanov et al., 2013).

The changing geopolitical and economic conditions and demand a new development strategy of the Kaliningrad industry. The previous import-substituting production facilities based on the duty-free import of raw materials and components from 1 April 2016 will lose their benefits. However, the companies will obtain financial support in accordance with the Government of the Russian Federation dated 29 November 2014 No 1275, but it will only soften the impact of the abolition of customs privileges and not return them or any associated economic mechanisms. In the new situation, the Kaliningrad industry appears to need movement towards increasing the share of products with a high added value, enhancing the quality and competitiveness of products and introducing innovative products and new technologies. In this context, small and medium enterprises could act as subcontractors of the region's leading industrial companies and at least partially replace foreign supplies. The transition to the innovative development of the regional industry will require greater integration of science (in particular, the Fabrika Science and Technology Park established in the I. Kant BFU; see Mikhaylova \& Mikhaylov, 2015) and production as well as the creation of new industrial parks and development of technology transfer mechanisms both within the region and from other Russian regions or abroad.

The current structure of the Kaliningrad region's manufacturing sector can be characterised by the dominance of the Avtotor Group of Companies, which in 2013 accounted for 12.5\% of the Kaliningrad region's GRP, 55\% of the Kaliningrad region's total production volume and $61.3 \%$ of the commodities of the region's manufacturing. In 2013 , the companies involved in the production of cars in the Kaliningrad region provided $48 \%$ of the regional rail car turnover and $71 \%$ of the regional container traffic. Avtotor is the largest regional taxpayer (at the end of 2013 the amount of tax liabilities to the budgets of all levels amounted to RUB 36.6 billion having increased by 4.4 times in comparison with 2009). Avtotor accounted for more than $80 \%$ of VAT collected in the region (Automotive industry should become the locomotive ..., 2014). The availability of such a locomotive, a growth driver is certainly an advantage for the region. At the same time, if this group of companies is not going to do well, it will negatively affect the whole economy of the Kaliningrad region. This was already evident in 2015, when Avtotor had to shift timing of the project designed to create a major automotive cluster in Kaliningrad and reduce car production (according to the forecast) to 80,000 against 186,000 in 2014because of the crisis and withdrawal of GM (Zakharov, 2015). The region's industry certainly needs the emergence and development of new industrial clusters and 'growth points'. As a result of the analysis carried out during the development of the Kaliningrad region's industrial policy concept (adopted on 27 August 2014), the following economic activities were added to priorities in the Kaliningrad region's manufacturing sector:

1. Manufacture of food products including beverages and tobacco;

2. Chemical industry (including the pharmaceutical production);

3. Manufacture of other non-metallic mineral products (building materials, composite materials and products 
associated therewith);

4. Manufacture of the electrical and optical devices (including the production of television and other consumer electronics);

5. Manufacture of transport vehicles and equipment (automotive, shipbuilding and ship repair);

6. Other types of production (manufacture of furniture, jewellery, amber articles and articles containing amber) (Resolution of the Kaliningrad Regional Government dated 27 August 2014..., 2014).

It is necessary to encourage the export of industrial products especially that in connection with the depreciation of the rouble the Russian (including Kaliningrad) products became more competitive in foreign markets in terms of price. For that purpose, in particular, it is necessary to bring them in line with the international standards and provide certification for compliance with these standards. Maximum efforts should also be taken to integrate Kaliningrad enterprises into the manufacturing process chains of Russian companies and overseas multinational corporations. The latter will provide good opportunities to avoid the effects of foreign economic sanctions (for example, Russian-made titanium parts and structures used for the production of Boeing and Airbus, and rocket motors used for launching the American satellites were excluded because of the economic sanctions that the US and EU had imposed on the Russian Federation).

The Kaliningrad region could become one of the Russian pilot regions of the so-called 'third industrial revolution' involving the introduction of advanced technologies, such as additive technologies (layer-by-layer synthesis technologies). To do this, it is essential to explore the possibility of creating a additive technology competence centre in the premises of one of the enterprises with the participation of Kaliningrad (not only) universities and research centres.

\section{References}

Afanasyev, N. (2006). Avtotor Agreed with KIA on Older Models. RBC. 03 March 2006. [Online] Available: http://www.rbcdaily.ru/ industry/562949979069012 (August 05, 2015).

Avtotor Reduces the Production of Cars in 2014 (2013). Economy News. 21.10.2013. [Online] Available: http://www.vestifinance.ru/ articles/34369 (August 05, 2015).

Avtotor Resumed the Production of Cars in Kaliningrad after the Break (2015). The Russian state news agency RIA Novosti. 02 February 2015. [Online] Available: http://ria.ru/economy/20150202/1045519341.htm (August 05, 2015).

Avtotor will Increase the Production of Cars by 2.3 Times (2010). Motor. 28 May 2010. [Online] Available: http://motor.ru/news/ 2010/05/28/avtotorl (August 05, 2015).

Denisenkov, A. (2009). The Cluster on the Edge of the Market. Expert. No 9 (648). 9 March 2009. [Online] Available: http://expert.ru/expert/2009/09/klaster_na_krayu_rynkal (August 05, 2015).

Fedorov, G.M. (2011). Social and Economic Development of the Kaliningrad Region: Tutorial. $2^{\text {nd }}$ revised and enlarged edition. Kaliningrad: Publishers of the I. Kant BFU.

Fedorov, G.M., \& Zverev, Yu.M. (1995). Kaliningrad Alternatives. Social and Economic Development of the Kaliningrad Region in the New Geopolitical Conditions: Monograph. Kaliningrad University - Kaliningrad.

Fedorov, G.M., \& Zverev, Yu.M. (2002). Social and Economic and Geopolitical Development of the Kaliningrad Region: Tutorial. Kaliningrad: Publishers of the Kaliningrad State University.

Gareyev, T.R., Zhdanov, V.P., Zverev, Yu.M., Fedorov, G.M., \& Tsikel, M.A. (2005). Establishing the Kaliningrad Region's New Economy. Kaliningrad: Publishers of the KSU.

Gimbitsky, K.K., Kuznetsov, A.L., \& Fedorov, G.M. (2014). The Economic Development of the Kaliningrad Region, Restructuring Stages, Baltic Region, 1 (19), 56-71.

Index of Industrial Production by the Territorial Entities of the Russian Federation (2015) (updated on 03 February 2015). Federal State Statistics Service. [Online] Available: www.gks.ru/free_doc/new_site/business/prom/ind_prom_sub.xls (August 05, 2015).

Industry of the Kaliningrad Region (2013). Statistical Book. Territorial Body of the Federal State Statistics Service in the Kaliningrad Region. Kaliningrad.

Kaliningrad Region in 2009 Figures (2009). Summary Statistical Book. Territorial Body of the Federal State Statistics Service in the Kaliningrad Region. Kaliningrad.

Kaliningrad Region in 2015 Figures (2015). Summary Statistical Book. Territorial Body of the Federal State Statistics Service in the Kaliningrad Region. Kaliningrad.

Khlopetsky, A.P., \& Fedorov, G.M. (2000). Kaliningrad Region, a Region of Cooperation: Monograph. Kaliningrad: Yantarny Skaz (Amber Tale).

Klemeshev, A.P., Kozlov, S.D., \& Fedorov, G.M. (2002). Island of Cooperation: Monograph. Kaliningrad: Publishers of the KSU.

Mikhaylova, A.A., \& Mikhaylov, A.S. (2015). Antecedents and Barriers to the Formation of Regional Innovation System: Case Study of the Kaliningrad Region. Modern Applied Science, 9 (2), 178-187.

Proportion of the Organisations Engaged in Technological Innovations (2013) The central statistical database. Federal State Statistics Service. [Online] Available:http://www.gks.ru/dbscripts/cbsd/dbinet.cgi?pl=9420108 (August 05, 2015).

Regions of Russia (2002). Social and Economic Indicators. 2002: Statistical Book / State Statistics Committee of the Russian Federation. $-M$. 
Report (2007). Report on the Results of Operation of the Special Economic Zone in the Kaliningrad Region in 2006. Kaliningrad: The Kaliningrad Regional Government, the Special Economic Zone Administration in the Kaliningrad Region.

Resolution of the Kaliningrad Regional Government of 27 August 2014 N 567 'On the Industrial Policy Concept of the Kaliningrad region'.

The Automotive Industry should be the Growth Drive for the Region's Economic Development (2014) Point. International Business Magazine. 25 April 2014. [Online] Available: http://www.tochka39.ru/index.php?id=1398432591 (05 August 05, 2014).

Zakharov, A. (2015) Avtotor Reduces Production by Two Times due to GM. Behind the Wheel. 13 April 2015. [Online] Available: http://www.zr.ru/content/news/776329-avtotor-sokratit-proizvodstvo-v-2-raza-iz-za-gm/ (August 05, 2015).

Zhdanov, V.P., Krasnyansky, I.Yu., \& Paletskaya, T.M. (2013). Evaluation of Development of the Economic Activities in the Kaliningrad Region in the WTO and Termination of the Transitional Period in the SEZ in 2016: Analytical Reviews by the Russian Institute for Strategic Studies (RISI). - M.: RISI.- No 1(36).

Zverev, Yu.M. (2006). Industry of the Kaliningrad Region. Geography and Environment in the School of the XXI Century, № 5, 20-25.

Zverev, Yu.M. (2010). Kaliningrad Region: Economic Recession Features (2008-2009) and Possible Ways of Recovery. Baltic Region, 2 (4), 16-27. 